\title{
COMMENTS
}

\section{Consequences of a Lease to a Third Party Made by One Joint Tenant}

Whether a lease for a term of years, made by one joint tenant in favor of a third party, effects a severance of the joint tenancy is the subject of a controversy going back to the time of Coke and Littleton. ${ }^{1}$ Dicta in several California decisions had indicated that such a transaction would not cause a severance. ${ }^{2}$ In Tenhet $v$. Boswell ${ }^{3}$ the California Supreme Court squarely faced this issue. The court unanimously held that where "a joint tenant leases his interest in the joint tenancy property for a term of years, and dies during that term . . . the lease does not sever the joint tenancy, but expires upon the death of the lessor joint tenant."4 This result is a significant break with common law authority, for it had long been settled that such a lease bound the other joint tenant after the death of the lessor. ${ }^{5}$ This Comment examines the rationale underlying this novel result and the consequences of the court's reasoning for the doctrine of severance in California. It concludes that this approach should be rejected as a doctrinal basis for future decisions. The Comment further argues that the court did not give adequate consideration to the competing policies involved and proposes an alternative solution to the problem posed by the facts of Tenhet.

I

SUMMARY OF THE OPINION

Raymond Johnson and Hazel (Johnson) Tenhet owned a parcel of property which they had acquired by a deed designating them joint tenants. Without Hazel's knowledge or consent Raymond leased the property to defendant Boswell for ten years at an annual rent of $\$ 150$. The lease did not disclose that the lessor owned only a joint interest in the property. Rather, it contained an "option to purchase" that granted the lessee a right of first refusal in the event of sale, implying that the lessor held a fee simple.

1. Co. LitT. *185, a, *186, b; LitTLETON’s Tenures $\S 289$ (1903); see 2 AMERICAN LaW OF PROPERTY $\S 6.2$ (A.J. Casner ed. 1952) [hereinafter cited as ALP].

2. See, e.g., Hammond v. McArthur, 30 Cal. 2d 512, 516, 183 P.2d 1, 3 (1947); County of Fresno v. Kahn, 207 Cal. App. 2d 213, 217, 24 Cal. Rptr. 394, 397 (2d Dist. 1962); Cole v. Cole, 139 Cal. App. 2d 691, 694, 294 P.2d 494, 495 (2d Dist. 1956); Swartzbaugh v. Sampson, 11 Cal. App. 2d 451, 454, 54 P.2d 73, 76 (4th Dist. 1936).

3. 18 Cal. 3d 150, 554 P.2d 330, 133 Cal. Rptr. 10 (1976) (Mosk, J.) (unanimous decision).

4. Id. at 152,554 P.2d at 332, 133 Cal. Rptr. at 12.

5. See note 17 infra and accompanying text. 
Raymond died three months after the execution of the lease. ${ }^{6}$ Hazel then sought to establish her right to exclusive possession of the property as the surviving joint tenant. When Boswell refused her demand to vacate the premises, Hazel brought an action to have the lease adjudged invalid. The trial court sustained a demurrer to the complaint, and plaintiff appealed. The supreme court reversed, holding that under the facts alleged the lease was no longer valid.

To provide a background for its analysis, the court reviewed the law of joint tenancy in California. ${ }^{7}$ Civil Code section 683 abolishes the common law presumption favoring joint tenancies and requires that to create a joint tenancy the creating instrument must contain an express declaration of the intent to do so. ${ }^{8}$ The court stated that this provision does not, however, abrogate the common law rule that four unities are essential to a joint tenancy: unity of interest, unity of time, unity of title and unity of possession. ${ }^{9}$ If any of these essential unities is destroyed, the joint tenancy is severed and a tenancy in common results. Severance extinguishes the principal feature of a joint tenancy, the right of survivorship. Thus, this right is not indestructible but accrues only if the unity of the estate has not been destroyed prior to the death of one of the joint tenants.

The court began its analysis by resolving the question whether the lease effected a severance of the joint tenancy. Finding no clear answer in existing authority, ${ }^{10}$ the court based its determination that "a lease is not so inherently inconsistent with joint tenancy as to create a severance, either temporary or permanent"11 on policy considerations. The court reasoned that since the legislature required an express declaration of intent to create a joint tenancy, the courts should not find severance except in circumstances that clearly and unambiguously establish the desire of one of the joint tenants to terminate the estate. Because alternative and unambiguous means of altering the nature of joint tenancy exist, ${ }^{12}$ the court held that the lease did not operate to sever the joint tenancy.

Having concluded that the joint tenancy was not severed by the lease, the court next considered whether the survivor takes the property unencum-

6. 18 Cal. $3 \mathrm{~d}$ at 153,554 P.2d at 332,133 Cal. Rptr. at 12.

7. Id. at $155-56,554$ P.2d at 334,133 Cal. Rptr. at 14.

8. CAL. CIV. CODE $\S 683$ (West 1954). Otherwise a tenancy-in-common results. Section 683 read in conjunction with CAL. CIv. CODE $\S 686$ (West 1954) creates a presumption in favor of tenancy in common.

9. See text accompanying notes 32 to 34 infra.

10. Compare Alexander v. Boyer, 253 Md. 511, 253 A.2d 359 (1969); 2 ALP, supra note 1, § 6.2; Swenson \& Degnan, Severance of Joint Tenancies, 38 MiNN. L. Rev. 466, 475 (1954) with Swartzbaugh v. Sampson, 11 Cal. App. 2d 451, 454, 54 P.2d 73, 76 (4th Dist. 1936); Co. LITT. *185, a; 27 HALSBURY's LAWS OF ENGLAND $\$ 1144$ (2d ed. 1937) [hereinafter cited as Halsbury's Laws]; Comment, 25 CaLIF. L. Rev. 203, 208 (1937) [hereinafter cited as 1937 Comment].

11. $18 \mathrm{Cal} .3 \mathrm{~d}$ at 157,554 P.2d at $335,133 \mathrm{Cal}$. Rptr. at 15.

12. See note 36 infra. 
bered by the lease. It analyzed the issue by analogy to cases involving liens and mortgages on joint tenancy property. ${ }^{13}$ These cases reason that a lien attaches only to the interest that the lienor joint tenant holds in the property. When the lienor dies, the lien expires with his interest, and the surviving joint tenant takes free of the lien. Similarly, the court reasoned that "because a lease is valid only insofar as the interest of the lessor in the joint property is concerned," the lease of the joint tenancy property also expires when the lessor dies. ${ }^{14}$

The court further explained that were a joint tenant permitted to lease for a term continuing after his death, the right of survivorship might be effectively nullified, defeating the justifiable expectations of the surviving joint tenant. ${ }^{15}$ Finally, the court rejected the argument that a contrary result is justified by the need to protect a person who in good faith leases from one joint tenant unaware that the lessor is not the fee simple owner. The court pointed out that such lessees can protect themselves by conducting title searches prior to leasing. ${ }^{16}$

\section{II \\ Discussion \\ A. The Logic of the Court's Analysis}

In holding that the lessee's rights are extinguished upon the death of the lessor joint tenant, the court reached a result that is virtually unprecedented. The courts and commentators since at least the sixteenth century have unanimously agreed that a lease by one joint tenant of her share to a stranger is binding on the survivor after the lessor's death. ${ }^{17}$ This common assump-

13. See, e.g., Hammel v. Gootkin, 202 Cal. App. 2d 27, 20 Cal. Rptr. 372 (2d Dist. 1962); People v. Nogarr, 164 Cal. App. 2d 591, 330 P.2d 858 (2d Dist. 1958); Zeigler v. Bonnell, 52 Cal. App. 2d 217, 126 P.2d 118 (1st Dist. 1942).

14. $18 \mathrm{Cal}$. 3d at 159,554 P.2d at 336, 133 Cal. Rptr. at 16 (quoting Swartzbaugh v. Sampson, 11 Cal. App. 2d 451, 458, 54 P.2d 73, 77 (2d Dist. 1936)).

15. The court hypothesized that:

[F]or personal reasons B might execute a 99 year lease on valuable property for consideration of one dollar a year. A would then take a fee simple on B's death, but would find his right to use the property -and its market value - substantially impaired. This circumstance would effectively nullify the benefits of the right of survivorship, the basic attribute of joint tenancy.

$18 \mathrm{Cal} .3 \mathrm{~d}$ at 159,554 P.2d at $337,133 \mathrm{Cal}$. Rptr. at 17.

16. Id. at $160,554 \mathrm{P} .2 \mathrm{~d}$ at $337,133 \mathrm{Cal}$. Rptr. at 17. The court does concede, however, that conducting a title search prior to leasing would be economically burdensome to a lessee of a residential dwelling or modest parcel of property. Id. Since leases of one year or less are unrecordable (CAL. CIv. CODE $\$ 1214$ (West 1954)) and hence not within the protection of the recording acts, it is arguable that the result in Tenhet does not apply to terms for less than one year.

17. See, e.g., Gould v. Kemp, 39 Eng. Rep. 959 (Ch. 1834) (dicta); Clerk v. Clerk, 23 Eng. Rep. 809 (Ch. 1694); Smallman v. Agborow, 79 Eng. Rep. 356 (K.B. 1615); Lampitt v. Starkey, 123 Eng. Rep. 880 (C.P. 1612) (dicta); Whitlock v. Horton, 79 Eng. Rep. 78 (K.B. 1604); Anonymous (1590), DYer *187, a; 2 ALP, supra note 1, § 6.2; H. Challis, Real PROPERTY 367 (3d ed. 1911); Co. LITT. *186, b; 27 HaLsBuRY's Laws, supra note 10, \& 1144; 1 T. PLATT, LAW 
tion has served as a predicate to the debate as to whether such a lease works a severance of the joint tenancy. ${ }^{18}$ Stated another way, the issue that has been controversial is whether the reversion is subject to survivorship, not whether the term is extinguished by the operation of that right. If the Tenhet court had begun its inquiry with the question whether a joint tenant can make a lease that is valid beyond his death, instead of first considering the question of severance in isolation, it would have found a uniform body of authority indicating that defendant Boswell was entitled to possession of the joint tenancy property, subject to the rights of Hazel as contenant, for the full extent of his term.

By making severance the central issue, the court focused on the wrong question. ${ }^{19} \mathrm{~A}$ more appropriate analysis would permit the question whether a lease is inconsistent with joint tenancy to turn fundamentally on whether the lease gives the lessee a right to possession that extends beyond the lessor's death. If, as the court suggested, continuation of the four essential unities is to be the test of severance, its application would seem to require a prior determination of the nature of the imterest conveyed. Whether a unity is destroyed must depend on the incidents of the interest conveyed by the joint tenant. ${ }^{20}$

OF Leases 127-29 (London 1847); 2 H. Tiffany, The Law of Real Property 8425 (3d ed. 1939); 1937 Comment, supra note 10 , at $207-08$.

18. The following authorities either hold or suggest that the lease continues and a complete and final severance of the joint tenancy results: Boyer v. Alexander, $253 \mathrm{Md} .511,253$ A.2d 359 (1969); In re Armstrong, [1920] 1 I.R. 239 (Ch.); Gould v. Kemp, 39 Eng. Rep. 959 (Ch. 1834); Clerk v. Clerk, 23 Eng. Rep. 809 (Ch. 1694); 2 ALP, supra note 1, § 6.2; Swenson \& Degnan, supra note 10, at $474 ; 1937$ Comment, supra note 10 , at 208 . The following authorities either hold or suggest that there is a temporary severance during the term of the lease with the possibility of revival if the term expires before the death of either joint tenant (i.e., if either joint tenant dies during the term a final severance results): Napier v. Williams, $1 \mathrm{Ch} .361$ (1911); Palmer v. Rich, 1 Ch. 134 (1897); Cowper v. Fletcher, 122 Eng. Rep. 1267 (K.B. 1865); Doe ex dem. Marsach v. Read, 104 Eng. Rep. 23 (K.B. 1810); Roe ex dem. Raper v. Lonsdale, 104 Eng. Rep. 16 (K.B. 1810); 2 H. TiffanY, supra note 17, $\$ 425 ; 2$ W. WALSH, CoMmentaries ON THE LAW OF REAL PROPERTY $\$ 116$ (1947); Comment, Severance of a Joint Tenancy in California, 8 HASTINGS L.J. 290, 293 (1957); 1937 Comment, supra note 10, at 208 n.48. The following authorities either hold or suggest that there is a temporary severance during the term to the extent necessary to protect the rights of the lessee but that in all cases no severance of the reversion results (i.e., the survivor takes the reversion subject to the lease in all cases): Smallman v. Agborow, 79 Eng. Rep. 356 (K.B. 1615); Whitlock v. Horton, 79 Eng. Rep. 78 (K.B. 1604); Anonymous, (1590), DYER *187, a; H. Challis, supra note 17, at 367; Co. LITT. *185, a; 24 HALSBURY's LAWS, supra note 10, \& 389; LITTLETON'S TENURES $\$ 289$ (1903); 1 T. PlatT, supra note 17, at 130; 2 G.W. ThOMPSON, REAL ProperTY, \& 1715 (1924); 2 H. TifFanY, supra note 17, § 425; Comment, Joint Tenancy in California Revisited: A Doctrine of Partial Severance, 61 CALIF. L. REv. 231, $242-44$ (1973); see also Annot., 64 A.L.R.2d 918, 932 (1959).

19. The conflicting characterizations the court gives to the interest created by the lease emphasize the weakness of the court's analysis. The court first concluded that a lease which purports to give the lessee a possessory estate in land for a term of years is not so "inherently inconsistent" with joint tenancy as to effect a severance. 18 Cal. $3 \mathrm{~d}$ at 157,554 P.2d at 335, 133 Cal. Rptr. at 15. Simultaneously, however, the court also determined that the right of survivorship "would be more illusory than real if a joint tenant were permitted to lease for a term continuing after his death." Id. at 160, 554 P.2d at 337, 133 Cal. Rptr. at 17.

20. To illustrate, consider the hypothetical of a conveyance by one joint tenant to a third party of a lease in futuro for a term of 10 years to begin upon the lessor's death. To say that 
It is curious that severance became a central issue at all, given the posture of the case. Boswell claimed his lease was binding on Hazel as the surviving joint tenant. Following common law authority that a lease made by one joint tenant is valid against the survivor, the court could have resolved the case on this ground alone. The issue of severance need not have been reached. ${ }^{21}$

If one looks beyond the surface logic of the opinion, the central holding of the case seems to be that a joint tenant may not "carve" out of her fee a leasehold interest that is valid beyond her death. In essence, the court held that a term for years when conveyed by one joint tenant is more a variety of life estate pur autre vie. The conclusion that a lease made by one joimt tenant to a stranger does not work a severance follows as a consequence of this result under the doctrine of four unities. In the court's parlance, a lease for a term is not so "inherently inconsistent" with joint tenancy as to work a severance because it does not convey what it purports, and for centuries has been understood, to convey: a possessory estate in land for a fixed term of years.

There may be legitimate policy grounds justifying the result the court reached. ${ }^{22}$ Its framework of analysis is unsatisfactory, however, because the primary rationale underlying its conclusion that a joint tenant may not partially alienate his interest by a lease for a term of years which continues after his death is that a lease is like a mortgage or other hen. ${ }^{23}$ First, as is demonstrated below, ${ }^{24}$ this proposition is both historically and technically

such a conveyance does not effect a severance because a lease is not inconsistent with joint tenancy, and yet that the lease expires upon the lessor's death is tantamount to saying the conveyance is nugatory $a b$ initio. That is, under traditional analysis the joint tenant who survives does not take the moiety of the deceased joint tenant as a successor in interest, but by right under the conveyance which created the joint tenancy. See Green v. Skinner, 185 Cal. 435 , 440, 197 P. 60, 62 (1921); Co. LITT. *185, a. Hence any interest created by one joint tenant in favor of a third party that does not work a severance expires if the grantor should predecease the other cotenant. To be more technical, the interest is void against the survivor because the survivor takes by superior title. Thus if one defers the question of whether the lease extends beyond the lessor's death until after a determination of whether a lease works a severance of the joint tenancy, the analysis becomes tautological: The conclusion that a lease does not sever also establishes the duration of the lessee's possessory rights under the lease. Not surprisingly, the court does not explain how one can determine whether a lease suspends the umity of possession without first fixing the possessory rights conveyed by the lease.

21. Severance was made the central issue presumably on the theory that if the lease did effect a severance, Hazel would take nothing by survivorship and the lease would be valid against Raymond's heirs or devisees. Of course, it would have been appropriate for the court to discuss the issue of severance after it determined the duration of the lease, even though such a discussion would have been dicta.

22. See text accompanying notes 30-31 infra.

23. As these decisions [i.e. those involving mortgages and other liens on joint tenancy property] demonstrate, a joint tenant may, during his lifetime, grant certain rights in the joint property . . . . But when such a joint tenant dies his interest dies with him, and any encumbrances placed on the property become unenforceable against the surviving joint tenant. For the reasons stated a lease falls within this rule.

$18 \mathrm{Cal} .3 \mathrm{~d}$ at $159-60,554$ P.2d at 337, 133 Cal. Rptr. at 17.

24. See text accompanying notes 40-54 infra. 
incorrect. Moreover, to make this analogy it is necessary to distort traditional notions concerning both the nature of the estate conveyed by a lease and the four unities to such an extent that the effect is to muddy the entire doctrine of severance. ${ }^{25}$ Finally, the court's statement that a lease is valid only as to the lessor's interest in the property begs the real question. Prior to Tenhet a joint tenant was understood to have an undivided moiety in fee simple for purposes of alienation. ${ }^{26}$ The conveyance of a term for years was thought to give the lessee an estate of shorter duration, but with a possessory right to the land for the full extent of the term leaving the lessor with only a reversion. ${ }^{27}$ The court's statement fails to explain why the alienation of an estate in land, which represents less than the joint tenant's total interest in the land at a time when the tenant had the right to make such a conveyance, is ineffective to convey what it purports to transfer.

The court's ancillary reasoning, that "[d]uring his lifetime, of course, [a joint tenant] . . . may sever or lease to a third party" 28 but to allow the joint tenant to lease for a term continuing after her death would defeat the "justifiable expectations" of the survivor and frustrate the "very purposes" of joint tenancy, fails to supply any independent analytic support for its conclusion. Rather, it rests on the presupposition that a lease does not effect a severance. If $B$ leases to $C$ for a term of years without $A$ 's knowledge and consent, why does the court value the expectations of the survivor to take an unencumbered fee over $B$ 's intent to convey to $C$ this possessory interest? It cannot be that $B$ and $C$ understood that $C$ was getting an interest only for $B$ 's life, for this imterpretation would be unjustified historically. ${ }^{29}$ It is because to allow the lease to continue would, at least in the court's view, entail the conclusion that a lease severs a joint tenancy, a conclusion it has already rejected.

The court's emphasis on the expectations of the survivor does, however, provide a clue as to the court's practical dilemma. It has been estimated that, of all deeds recorded in California, sixty-nine percent are to husband and wife, and of these eighty-five percent are to them both as joint tenants. ${ }^{30}$ Further, joint tenancy is used primarily as a device, in lieu of a will, to leave the property to a surviving spouse, because it avoids the delay

25. See text accompanying notes 55-58 infra.

26. Co. LrTT. *186, a; see Burke v. Stevens, 264 Cal. App. 2d 30, 34-35, 70 Cal. Rptr. 87, 91 (5th Dist. 1968); Swartzbaugh v. Sampson, 11 Cal. App. 2d 451, 457-58, 54 P.2d at 73, 76-77 (2d Dist. 1936); 2 ALP, supra note 1, \& 6.2; Annot., 64 A.L.R.2d 918 (1959).

27. Satterlee v. Bliss, $36 \mathrm{Cal} .489$, 517 (1869); 1 H. TiFFANY, supra note 17, $8 \S 76,94$. See 30 CAL. JUR. 2d. Landlord and Tenant § 5 (1956) [hereinafter cited as CAL. JUR. Landlord \& Tenant].

28. 18 Cal. 3d at 160, 554 P.2d at 337, 133 Cal. Rptr. at 17.

29. See note 53 infra and accompanying text.

30. Griffith, Community Property in Joint Tenancy Form, 14 STAN. L. Rev. 87, 88 (1961). The fact that the joint tenants are husband and wife may interject further complications into the Tenhet analysis. See notes 67-68 infra. 
and administrative expenses of probate. ${ }^{31}$ The dilemma posed is thus: If $B$ makes a lease to $C$ for one year, was it intended that the property should not go to $B$ 's spouse by operation of the right of survivorship? The answer clearly would seem to be no. If the right of survivorship were vulnerable to destruction by a one year lease, joint tenancy would be substantially impaired as an estate planning device, its manifest function. Distinguishing between leases that should defeat the right of survivorship and those that should not entails substantial administrative difficulties, however. The court's result does avoid these problems. But its reasoning distorts the nature of the modern leasehold and muddles the four unities test for severance.

\section{B. The Doctrine of Severance}

Fundamental to any consideration of the problem of joint tenancy and severance is a discussion of the four unities test. To create a joint tenancy four unities must be present. ${ }^{32}$ Unity of interest requires that each joint tenant have the same interest in the property. One may not have an interest that is different is quality or quantity from that of the others. The unities of time and title require that all joint tenants take by the same deed and that the interest of each vest at the same time. Unity of possession requires that each joint tenant have the right to possession of the whole property. The requirement of four unities expresses in a somewhat artificial way the basic concept that joint tenancy is a single estate held by the cotenants as a fictitious unity, ${ }^{33}$ as though they together constituted one person, rather than as the separate interests of each individual. ${ }^{34}$

Tenhet reaffirms this common law four unities test, which has long been approved by the California courts. ${ }^{35}$ The court modified the test, however, by adding the proviso that severance should be found only in

31. Id. at 108-09. It is in fact cheaper only in "no tax" cases, i.e., when used by persons of modest means. In all cases, however, it is only necessary to record a certificate of death and obtain an inheritance tax clearance in order to immediately give the survivor marketable title.

32. Siberell v. Siberell, 214 Cal. 767, 7 P.2d 1003 (1932); DeWitt v. San Francisco, 2 Cal. 289, 297 (1852); W. BLACKSTONE, CoMmentaRIES *180, 2 H. TiffaNY, supra note 17, § 418.

33. The requirement is feudal in origin; it was to the advantage of the lord that each feudal tenure be a single feud continuing until the death of the survivor. 2 ALP, supra note $1, \S 6.1$. This advantage of joint tenancy has long disappeared and in modern times the requirement of four unities has been relaxed accordingly, both in terms of the creation and continuation of joint estates. See, e.g., Swenson \& Degnan, supra note 10, passim. See also Comment, Severance of a Joint Tenancy in California, 8 HASTINGS L.J. 290 (1957); Note, 36 CaLIF. L. REv. 133, 135 (1948).

34. Joint tenants are said to be seized per my et per tort; each has a right to an undivided moiety in fee "to enfeoffe give or demise," Co. LIrT. *186, a; see Burke v. Stevens, 264 Cal. App. 2d 30, 34-35, 70 Cal. Rptr. 87, 91 (5th Dist. 1968); Swartzbaugh v. Sampson, 11 Cal. App. 2d 451, 457-58, 54 P.2d 73, 77 (4th Dist. 1936); 2 ALP, supra note 1, \& 6.2; Annot., 64 A.L.R.2d $918, \S 3$ at $923-25$ (1959).

35. See, e.g., Hammond v. McArthur, 30 Cal. 2d 512, 183 P.2d 1 (1947); Siberell v. Siberell, 214 Cal. 767, 7 P.2d 1003 (1932); Swartzbaugh v. Sampson, 11 Cal. App. 2d 451, 54 P.2d 73 (4th Dist. 1936). 
circumstances that clearly and unambiguously establish the desire to terminate the joint estate, indicating that a rigid and formal application of the four unities would be inappropriate in the context of modern joint tenancy. If the result in Tenhet is indicative of the operation of this "qualified four unities test," however, it is doubtful that the concepi of the four unities will any longer be useful to the Bar as a gauge of the impact of any given action on a joint tenancy estate. Further, it may be wondered whether any action save those enumerated by the court ${ }^{36}$ will in the future be construed to work a severance.

Although, as Tenhet demonstrates, the four unities have not been totally abandoned, the modern trend has been rather to focus on the intent with respect to the primcipal element of joimt tenancy, the right of survivorship, in determining whether a given transaction has effected a severance. ${ }^{37}$ This is a sound and realistic approach, particularly in view of the fact that the modern function of joint tenancy is as a testamentary device. The California courts have been especially inclined to take this approach when the transaction involved is between the joint tenants inter se. Their rationale is to examine the extent to which the transaction is consistent with the right of survivorship. On this basis the courts then infer whether the parties intended to sever the joint tenancy. ${ }^{38}$ The four unities test has had an

36. The actions enumerated by the court that operate to sever a joint tenancy are as follows: written mutual agreement, conveyance by one joint tenant of his entire interest to a third party, involuntary alienation under execution, joint conveyance by all joint tenants of the property to a third person and division of the proceeds, and a judgment in a partition proceeding. $18 \mathrm{Cal}$. 3d at 155-56, 554 P.2d at 334, $133 \mathrm{Cal}$. Rptr. at 14.

37. See, e.g., Hammond v. McArthur, 30 Cal. 2d 512, 183 P.2d 1 (1947); McDonald v. Morley, 15 Cal. 2d 409, 101 P.2d 690 (1940); Wardlow v. Pozzi, 170 Cal. App. 2d 208, 210, 338 P.2d 564, 565 (3d Dist. 1959); Tindall v. Yeats, 392 Ill. 502, 64 N.E.2d 903 (1946); O'Connor v. Dickerson, 188 So. 2d 241 (Miss. 1966); In re Armstrong, [1920] 1 I.R. 239, 242 (Ch.) ("when an act done by either joint tenant is inconsistent with the chief characteristic of a joint tenancy, namely survivorship, it is reasonable to assume that such act should effect a severance").

38. The often discussed case of Hammond v. McArthur, 30 Cal. 2d 512, 183 P.2d 1 (1947), is exemplary. The facts are as follows: $A$ and $B$ are joint tenants; $A$ conveys a life estate to $B$; $B$ subsequently dies prior to $A ; B$ 's administrator claims a one-half interest in the property on the ground that the conveyance of the life estate effected a severance. Although the court set forth the four unities test in a somewhat perfunctory fashion, it is clear from the opinion that the holding that no severance resulted from the conveyance did not rest on a technical preservation of the unities but rather on a finding that the conveyance was not inconsistent with the right of survivorship. See Comment, Joint Tenancy in California Revisited: A Doctrine of Partial Severance, 61 CALIF. L. REv. 231 (1973); Note, 36 CALIF. L. REv. 133 (1948); Note, 21 S. CAL. L. REv. 295 (1948). In a similar fashion it has been held that a lease for life made by one joint tenant to the other or an agreement giving one joint tenant exclusive possession for life does not sever the joint tenancy. Toth v. Crawford, 212 Cal. App. 2d 827, 829-30, 28 Cal. Rptr. 343, 344 (2d Dist. 1963); Cole v. Cole, 139 Cal. App. 2d 691, 294 P.2d 494 (2d Dist. 1956); Spahn v. Spahn, 70 Cal. App. 2d 791, 162 P.2d 53 (2d Dist. 1945); accord Tindall v. Yeats, 392 Ill. 502, 64 N.E.2d 903 (1946).

On the other hand, an agreement giving one joint tenant exclusive possession until the property could be sold for a specified sum, Pike v. Pike, 208 P.2d 380 (2d Dist. 1949), an agreement between husband and wife that on the death of either his or her share should go to their daughter, McDonald v. Morely, 15 Cal. 2d 409, 101 P.2d 690 (1940), and an agreement 
insignificant role in this context, and the impact of Tenhet, if any, is likely to be to further attenuate its importance. ${ }^{39}$

The four unities have been analytically more important in the California decisions involving a claim that a severance of the joint estate has resulted from a third party having acquired soine right, title, or interest in the moiety of only one of the joint tenants. Among these are the cases on which Tenhet relies, those where one joint tenant has mortgaged or suffered the imposition of a lien on his interest in the joint tenancy property and dies before the creditor can enforce the lien. The assimilation of the problem posed in Tenhet to the rationale of this line of cases ${ }^{40}$ not only is unjustified

providing that on a specified date either joint tenant would have the right to buy the other's share of the property or that it would be sold and the proceeds divided, Wardlow v. Pozzi, 170 Cal. App. 2d 208, 338 P.2d 564 (3d Dist. 1959), have all been held to work a severance.

The courts have on occasion relied on technical arguments showing the destruction or preservation of the four unities to justify their holdings. The cases, however, are conflicting and difficult to reconcile if these arguments are taken seriously. For example, in Cole the court found that an agreement giving one joint tenant the right to exclusive possession did not destroy any of the unities, while the court in Pike found such an agreement to destroy the unities of interest and possession. If one focuses on the consistency of the agreements with respect to the right of survivorship (as did the courts in the alternative) these cases become harmonious, and intelligible within a single framework.

39. Although the courts do not seem to have explicitly made the connection, transactions between joint tenants are similar to transactions with third parties in which all joint tenants join. That is, a transaction between $A$ and $B$ (joint tenants) agreeing, for example, to give $B$ exclusive possession of the property, can be construed as a transaction between $A, B$ and $B$, and equivalent to a transaction between $A, B$ and $X$, a third party. When $A$ and $B$ grant to $X$ a term for years or a life estate or agree that $X$ is to have the right to possession for a certain period, no severance results. That $A$ and $B$ remain joint tenants in the reversionary interest has never been controversial. See, e.g., Gillette v. Nicolls, 121 Cal. App. 2d 185, 262 P.2d 856 (4th Dist. 1953); Palmer v. Rich, 1 Ch. 134 (1897); Co. LITT. *92, a; 24 HalsBurY's Laws, supra note 10, § 389, at 205. LitTLEToN's TeNuRES § 574 (1903); Annot., 64 A.L.R.2d 918, §§ 12, 15 (1959). $A$ and $B$ should be able to agree to grant similar rights to $B$ without severing the joint estate.

Thus $A$ and $B$ should be able to make any arrangements they choose concerning the property inter se, short of agreeing to dispose of the property or to convey the interest of one to the other, without effecting a severance. See, e.g., Smith v. Morton, 29 Cal. App. 3d 616, 106 Cal. Rptr. 52 (1st Dist. 1972); Wardlow v. Pozzi, 170 Cal. App. 2d 208, 338 P.2d 564 (3d Dist. 1959); O'Connor v. Dickerson, 188 So. $2 d 241$ (Miss. 1966). The requirement imposed by Tenhet that the circumstances clearly and unambiguously establish the desire to terminate the joint estate seems to ensure this result. The analogy to third party transactions suggests that it will probably always be possible with some ingenuity to construct a technical argument demonstrating that the four unities have been preserved. But given the presumption against severance, to apply the four unities with any rigor in this context would be.to engage the courts in a course of pedantry. If "clear and unambiguous" is to be the standard, then the extent to which the action taken is consistent with the right of survivorship is a far more straightforward and meaningful test of whether the parties have expressed the desire to end the joint tenancy relationship. Of course, the four unities are still to some extent relevant in determining whether a transaction is consistent with the right of survivorship.

40. On the surface the opinion appears to assimilate the case of the lease to that of the lien only in respect to the issue of whether the interest created in favor of the third party is good as against the survivor. Tenhet actually does more than this. The lien cases are based on the common law rule that survivorship is preferred to charges or encumbrances. See note 43 infra and accompanying text. The theory behind this rule is that because charges or encumbrances 
in terms of modern learning concerning leases and liens, but also puts the conceptual apparatus of the four unities in jeopardy as a meaningful tool for legal analysis.

The common law categories of "lease" and "charge or encumbrance upon the land" 41 have for centuries been separate and distinct in the theory of joint tenancy..$^{42} \mathrm{~A}$ mere charge or encumbrance upon the land created no possessory rights in the land and did not bind the survivor. That is, it was not considered to be a conveyance in the land itself. ${ }^{43}$ In contrast, a lease gave the lessee, for the term, all the rights to possession that the lessor had, and was good as against the survivor. ${ }^{44}$ It is because mortgages and other liens are similar to other interests that have traditionally been within the category of "charge upon the land" (i.e., a California mortgagee has no right of possession nor any of the other incidents of ownership) that such imterests "fall off" and are void as against the survivor. On the other hand, the modern lease has, at least since the beginning of the sixteenth century, given the lessee a right to possession that may be enforced against "all the world" and that divests the lessor of any possessory rights. ${ }^{45}$ To treat the lease and the mortgage as identical thus undermines the very notion of unity of possession. A close analysis of the modern incidents of mortgages and leases in California demonstrates the implausibility of treating these two interests as similar.

The modern California mortgage bears little resemblance to the classical common law mortgage. California's departure from the common law

represent no disposition of the land itself, i.e., create no estate in the land, there is no severance. Hence when the right of survivorship accrues, the survivor's title is paramount to such charges or encumbrances. That is, because a lien can attach only to such interest in the property as the debtor has, when the debtor's interest is terminated by his death, the lien also expires.

On the other hand, the lease has for centuries been considered to be a conveyance in the land itself, and hence good against the right of survivorship. In contrast to this line of authority, Tenhet assimilates the lease to the rule that governs liens. This assimilation in effect reclassifies the nature of a leasehold interest, just as People v. Nogarr, 164 Cal. App. 2d 591, 330 P.2d 858 (2d Dist. 1958), reclassifies the California mortgage as a lien. See notes $46-51$ infra and accompanying text. Since from the fact that an interest is classified as a mere lien or encumbrance in the theory of joint tenancy it follows that such an interest can create no severance, the second step of the Tenhet analysis renders the first superfluous.

41. The modern lien is considered to be within the category "charge or encumbrance." 2 H. TIFFANY, supra note 17, at 210-211.

42. See, e.g., Co. LrrT. *185, a.

43. Lord Coke states the rule to be "jus accrescendi praefertus oneribus." Co. LITT. *185, a ("the right of survivorship is preferred to encumbrances"). See also 24 HaLSBURY's

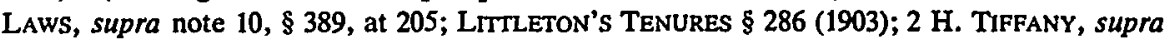
note $17, \S 419$, at $199 \& \S 425$, at 211 .

44. See, e.g., Co. LIrT. * ${ }^{*} 185$, a, ${ }^{*} 186, \mathrm{~b} ; 27$ HalsBury's Laws, supra note 10, $\$ 1144$; LITTLETON'S TENURES $\$ \S 286-289$ (1903).

45. T. Plucknetr, A Concise History of the Common Law 574 (5th ed. 1956); ReSTATEMENT (SECOND) OF Property, Landlord and Tenant, Intro., at 1-3 (Tent. Draft No. 1, 1973) [hereinafter cited as Restatement]. See also Hammel v. Zobelein, 51 Cal. 532, 533 (1876); Uttendorffer v. Saegers, 50 Cal. 496, 498 (1878); 1 H. TIFfaNY, supra note 17, § 94. 
rule that a mortgage severs a joint tenancy ${ }^{46}$ can largely be explained by the differences between the two. In California the mortgagee has no right whatsoever in the land, except as security for the debt. ${ }^{47}$ In contrast, the classical common law mortgage consisted of the conveyance of a fee interest to the mortgagee with a covenant for reconveyance on payment. It appears that as late as the middle of the seventeenth century mortgagors generally gave up possession to their mortgagees. ${ }^{48}$ Hence, the common law rule that a mortgage of one joint tenant's interest in the joint tenancy property worked a severance resulted from a destruction of the unities of title and possession. In jurisdictions in which a mortgage still operates to transfer title to the mortgagee, the common law rule of severance still prevails. ${ }^{49}$ In California, however, because no title or possessory rights inure to the mortgagee, the imposition of a mortgage or other lien on the share of one joint tenant technically destroys none of the unities. ${ }^{50}$ Thus, under modern California law, severance need not result. ${ }^{51}$

In contrast, not even a technical preservation of the four unities is possible when one joint tenant leases his interest in the joint tenancy property. ${ }^{52}$ Under modern California law, for the duration of the term the

46. 2 ALP, supra note 1, § 6.2; Swenson \& Degnan, supra note 10, at 488-92.

47. J. Hetland, Secured Real Estate Transactions $65-66$ (1974). Further, upon a default in the repayment of the underlying obligation no possessory rights or rights of title to the land accrue to the mortgagee. The mortgagor has an equity of redemption that the mortgagee must foreclose, which allows the mortgagor at any time before foreclosure to cure the default and keep the land. Whether the mortgagee proceeds judicially or non-judicially there exists no right to strict foreclosure, i.e., to retain the land in satisfaction of the debt. The mortgagor may always insist upon a public sale. See J. HETLAND, supra, passim.

48. T. PLUCKNETT, supra note 45 , at 607-08. If payment was not made by the specified date the mortgagee took absolute title to the land in satisfaction of the debt. Id.

49. As the court in People v. Nogarr explained with approval,

It is evident that in those jurisdictions where a mortgage operates to convey title to the mortgagee the unity of title is destroyed and in those jurisdictions where it operates not only to transfer title but the right of possession . . . both the unity of title and of possession are destroyed and that in either case there is a severance of the joint tenancy.

164 Cal. App. 2d 591, 596, 330 P.2d 858, 860 (2d Dist. 1958).

50. Under the law of this state a mortgage is but a hypothecation of the property mortgaged. It creates but a charge or lien upon the property hypothecated without the necessity of a change of possession and without any right of possession in the mortgage and does not operate to pass the legal title to the mortgagee.

Inasmuch as the mortgage was but a lien or charge upon [the mortgagor joint tenant's] interest and as it did not operate to transfer the legal title or any title to the mortgagees or entitle the mortgagees to possession it did not destroy any of the unities and therefore the estate in joint tenancy was not severed . . . .

Id. at 594, 330 P.2d at 860-61 (citations omitted).

51. The rules with respect to mortgages, judgment liens and deeds of trust are identical. See cases cited note 13 supra. A deed of trust is treated on par with these other interests although technically it is not a lien and it operates to convey legal title to the trustee. This is because the trustee has a "naked" legal title for security purposes only, the trustor being the legal owner for all other purposes. Any other result would be anomolous given that the deed of trust and the mortgage have identical economic functions and are equated for almost all other legal purposes. Hammel v. Gootkin, 202 Cal. App. 2d 27, 20 Cal. Rptr. 372 (2d Dist. 1962).

52. The rights of lessors and lessees are defined by a unique combination of "property law" and "contract law" that can only be properly understood in historical terms. As it 
lessee is equivalent to a fee owner for a wide range of purposes. Most fundamentally, the lessee is granted a right to possess the property and the lessor largely deprived of that right. ${ }^{53}$ Thus, the application of the four unities test in Tenhet, whereby the court concludes that the lease effects no severance, temporary or permanent, actually conflicts with the lien cases. If in a jurisdiction where a mortgage operates to transfer title and possession, the unities of title and possession are suspended if one joint tenant's interest is mortgaged, it should follow that a lease made by one joint tenant to a third

originated, a term for years was not regarded as an estate in land, but merely a contractual relationship between the lessor and lessee; and for a considerable period actions involving the term were not heard with real actions at the assizes. T. PLUCKNETT, supra note 45, at 572-76. Pollack and Maitland ascribed this to the influence of Roman law which would put the term for years on par with the usufruct. 2 F. POLLACK \& F. MAITLAND, THE History OF ENGLISH LAW 114-15 (2d ed. 1898). This view is now being supplanted, however, by the more useful economic interpretation that the term was a response to the church's strict prohibitions against usury. See T. PLUCKNETT, supra note 45, at 571-73. Initially the termor had no protection against third parties and had to be content with enforcing a covenant of quiet enjoyment against lessor. Id. at 571 . With the rise of the husbandry lease, however, and the disassociation of the term from the unsavory business of usury, the termor was gradually afforded more protection through the writ de ejectione firmae, which gave protection against third parties. At first the termor could only recover damages, but by the beginning of the 16th century actual possession could bc recovered with relative speed and convenience. Id. at 573-74. Thus "[e]ventually the contract aspect was completely overwhelmed, the lease came to be regarded almost wholly as a conveyance and the landlord was thought to have surrendered almost all of his interest in the premises for the term." RESTATEMENT, supra note $45, \S 1$ at 4.

53. A lease for a term of years is a conveyance in land and is as much an interest in land as a fee simple, although it is not an interest in real property but a chattel real. See Parker v. Superior Court, 9 Cal. App. 3d 397, 88 Cal. Rptr. 352 (4th Dist. 1970); CAL. JuR. Landlord and Tenant, supra note $27, \S \S 2,5$. The lessee succeeds to all the possessory rights of the lessor, the lessor having no right to entry for the term. Rider v. Clark, 132 Cal. 382, 386, 64 P. 564,565 (1901); Bess v. White, 275 Cal. App. 2d 158, 79 Cal. Rptr. 611 (1st Dist. 1969); Yee Chuck v. Board of Trustees, $179 \mathrm{Cal}$. App. 2d 405, 3 Cal. Rptr. 825 (1st Dist. 1960). Hence the lessee's right to possession is as complete for all purposes of redress against wrongdoers as is that of an owner in fee simple. Brown Derby Hollywood Corp. v. Hatton, 61 Cal. 2d 855, 395 P.2d 896; 40 Cal. Rptr. 896 (1964); Strohlburg v. Jones, 78 Cal. 381, 20 P. 703 (1889). Thus the lessee may recover possession from the lessor or a third party in ejectment, and may bring an action for trespass without joining the lessor even though the injury is to the freehold. The lessor, on the other hand, has no possessory rights as would allow the bringing of an action for trespass. The lessor's protection is limited to the rights granted under CAL. Civ. CoDE $\S 826$ (West 1954), which allows the lessor to sue to protect against injury to the estate of inheritance. See Uttendorffer v. Saegers, 50 Cal. 496 (1875); CAL. JUR. Landlord \& Tenant, supra note 27, §§ $114 \& 171$. As against the lessor's cotenants, the lessee has all the rights of possession to the entire property formerly enjoyed by the lessor joint tenant. Swartzbaugh v. Sampson, 11 Cal. App. 2d 451, 54 P.2d 73 (4th Dist. 1936). The cotenants have no right to exclude the lessee or interfere with his right to possesion. If they do, the lessee may bring an action of trespass against them and has the right to be let into possession. See Verdier v. Verdier, 152 Cal. App. 2d 348, 313 P.2d 123 (1st Dist. 1957). Moreover, a lessor who sells the freehold conveys a mere reversion, the term having been "carved" out of the larger estate. Thus the purchaser takes subject to the lease and stands in the shoes of the lessor vis-a-vis the lessee. See CaL. JuR. Landlord \& Tenant, supra note 27 , at $\$ \S 83 \& 210$. 
party also suspends the unity of possession, since the joint tenant parts with all possessory rights in the property for the term. ${ }^{54}$

Since the term may end before the lessor's death, the grant of a lease does not necessarily entail the destruction of the unity of possession at the time the right of survivorship accrues. Hence it is hard to justify the conclusion that a permanent severance results at the time the lease is executed. This reasoning, however, will not support the conclusion that there is no temporary severance for the term of the lease. At the time the term is conveyed, the lessor holds a fee interest for the purposes of alienation. The other joint tenant's interest in this fee qua the right of survivorship is a mere expectancy. At least under traditional doctrine, an estate in the land conveyed before the right of survivorship accrues is good as against the survivor. ${ }^{55}$ Thus, the contingency that the term inay continue beyond the death of the lessor leads to the conclusion that there is a temporary severance of the joint tenancy for the term, at least for the purpose of determining the rights of the lessee as against the survivor ${ }^{56}$ Since the freehold has not been separated from the reversion, however, there may not even be a temporary severance of the reversion. ${ }^{57}$

If the unities of possession and interest are not held to be suspended during the term of the lease, at least for the purposes of determining the rights of the Jessee and the survivor inter se, it is difficult to determine what action will work a severance. Under the Tenhet rule, it is not clear even when a joint tenant parts with all possessory rights for an indefinite period, as when she conveys a life estate, that any of the unities of estate are necessarily destroyed. For example, it could be said that a life estate is not "inherently inconsistent" with joint tenancy, for a life estate granted by one joint tenant may terminate due to the death of the holder before the death of the grantor. A life estate could therefore be considered a mere encumbrance within the ineaning of Tenhet. The four unities provide no clear guide. In parity with the court's analysis of the lease, it could be argued that sucl a conveyance is really more a variety of a life estate pur autre vie. Of course if this logic is taken to the limit, one could conclude that the right of survivorship is indestructible and that a joint tenancy is really more a form

54. Likewise, since the lessor joint tenant parts with those same rights for the purpose of alienation, the unity of interest should also be held to be suspended.

55. See notes 17-18 supra and accompanying text.

56. This analysis and conclusion are in no way inconsistent with nor do they undermine the cases involving liens. To analyze the interest created by a mortgage in terms of the four unities, it is not necessary to determine if the mortgage is enforceable as against the survivor. Quite apart from whether it is enforceable after the death of the mortgagor, it is possible to determine that a mortgage destroys none of the unities until foreclosed. Hence if the mortgage has not been foreclosed before the mortgagor's death, the right of survivorship accrues at a time when the unity of estate is whole, and under the maxim jus accrescendi praefertur oneribus the survivor prevails. See note 43 supra.

57. See Co. LitT. *192, *185, a; LitTleton’s Tenures $\$ 302$ (1903). See also Section III.D infra. 
of joint life estate with cross remainders in fee, ${ }^{58}$ a conclusion the court clearly considers unacceptable. The point is simply that one's confidence in the four unities as a tool for analysis is undermined by the rationale of Tenhet.

\section{Competing Interests of the Lessor, Lessee, and Survivor}

As the opinion explains, if $A$ and $B$ agree to hold property as joint tenants, $B$ may sever or lease his interest to a third party during his lifetime. Upon $B$ 's death, however, $A$ may " "reasonably expect" to take an unencumbered fee simple. Hence $B$ cannot be allowed to lease for a term continuing beyond his death (assuming $B$ predeceases $A$ ) because to allow this would indirectly defeat the very purposes of the joint tenancy. Protection of the "justifiable expectations" of the survivor is a laudable goal, especially since joint tenancy is used primarily as a device, in lieu of a will or some other means, of ensurmg that a surviving spouse will receive the property that is the subject of the joint estate. ${ }^{59}$ Against this interest, however, should be weighed the interests of the lessor joint tenant and of the lessee. In reaching its decision, the court failed to consider the impact of its result on the lessor's right to alienate an interest in the joint property. The court did briefly discuss the lessee's right to the term bargained for, concluding that the lessee's interest is sufficiently protected by the recording acts. The court neglected to consider, however, the interrelationship of its decision with the lessee's right of quiet enjoyment under Civil Code section 1927. These interests will next be examined.

\section{Alienation}

Not allowing one joint tenant to lease for a term continuing after that joint tenant's death poses no absolute restraint on the right of alienation for the joint tenancy may be severed before the lease is made. ${ }^{60} \mathrm{~A}$ joint tenant may not, however, make such a lease and at the same time retain the benefits of joint tenancy. Since $B$, by severing, may still make a ninety-nine year lease that is valid for the full extent of the term, it cannot be that the court is simply worried that $B$ will encumber the property. If $B$ severs and makes such a lease, $A$ is no better off than if required to take the property subject to the lease. $A$ may in fact be worse off, if one assumes that the reversion has incident to it a valuable yearly rent. Embodied in the court's

58. In fact, in jurisdictions where the joint tenancy form of ownership has been abolished by statute, this very construction is given to joint tenancy deeds. See, e.g., Holbrook v. Holbrook, 240 Or. 567, 403 P.2d 12 (1965), construing OR. REv. STAT. $\$ 93.180$.

59. See notes 30-31 supra and accompanying text.

60. $B$, for example, may sever the joint tenancy yet still retain her share of the property by a conveyance and reconveyance to herself through a third party (either before making the lease or at a later time before her death). As a result of such a severancc, upon $B$ 's death, $B$ 's heirs or devisees will take the reversion as successors in interest and hence will be bound by the lease. 
conclusion that the "very purposes" of joint tenancy would be defeated if $B$ could both lease beyond $B$ 's death and have the chance at being the survivor thus seems to be some notion of mutuality. That is, if $B$ could make such a lease, $B$ would be able to extract a substantial portion of the value of the joint tenancy interest, either through obtaining the satisfaction of seeing the property go to a relative or loved one for one dollar per year, or by obtaining the full rent for the term in advance, and still have a chance of taking $A$ 's share unencumbered. ${ }^{61} \mathrm{~B}$ may not have the cake and eat it too. ${ }^{62}$

The Tenhet rule does more than enforce this mutuality, however. As a practical matter, it also places a restraint on a joint tenant's ability to alienate her interest by lease during her lifetime. For example, in Swartzbaugh $v$. Sampson $^{63} A$ and $B$, spouses, owned as joint tenants sixty acres of land devoted to agriculture. $C$ entered into negotiations with $A$ and $B$ to lease a portion of this land as a site for a boxing arena for a term of five years with an option to renew. At all times $A$ objected to making the lease and communicated to $C$ that she would not join in any lease to him. $B$ nevertheless wanted to make the lease. ${ }^{64}$ After Tenhet, $C$ may be unwilling to lease from $B$ alone under such circumstances unless $B$ agrees to sever the joint estate, because the contingency that the lease may expire prematurely may create a risk of sufficient magnitude to deter $C$ from entering the transaction without a guaranteed term. The capital investment in building the arena and other costs incurred in establishing a new business may require that $C$ be in possession for a number of years before reaping any profits. So long as $B$ desires to continue the joint tenancy relationship, $A$ thus effectively has a veto power over any proposed lease of significant duration.

61. See $2 \mathrm{~W}$. WALSH, supra note 18 , at $12-13$, making a similar argument in criticism of the result in Wilkens v. Young, 144 Ind. 1, 41 N.E. 68 (1895) (holding that because a mortgage is merely a lien, it does not sever the joint tenancy, but that the survivor takes subject to the rights of the mortgagee).

62. It is far from self-evident that the concept of mutuality, which has been nothing but a thorn in the side of the law of contracts, should be applied in the context of joint tenancy. See Swenson \& Degnan, supra note 10 , at $491-92$. But see Co. LITT. ${ }^{*} 193$, a. Beyond the implication that A's "justifiable expectations" arise from an agreement between A and B to create a joint tenancy, the opinion offers no supporting analysis. As the facts of Tenhet show, however, this is not the only mode of creation: a joint tenancy may arise from a conveyance to $A$ and $B$ by a third party. Further, if the primary modern function of joint tenancy is simply as a device to avoid the time and expense of probate, it is difficult to see the source of the survivor's expectations of taking free of the lease, for if the surviving joint tenant took instead by descent or devise the lease would be binding. Moreover, it is doubtful the chimera of the 99-year lease for one dollar a year or the payment of the entire rent for a 99 -year term in advance (representing the full market value of the possessory right) has much basis in economic reality. Hence, little serious danger of inequity exists in the vast majority of cases. See text following note 90 infra.

63. 11 Cal. App. 2d 451, 54 P.2d 73 (4th Dist. 1936).

64. $B$ and $C$ ultimately did enter into a lease purporting to give $C$ the right to exclusive possession. $A$ then brought an action to cancel the lease. The court held the lease was valid insofar as B's interest in the property. $11 \mathrm{Cal}$. App. $2 \mathrm{~d}$ at 462,54 P.2d at 79. 
The court does not seem to fully apprehend this restraint, for it states that a cotenant may alienate his interest by lease during his lifetime without severing the joint estate. ${ }^{65}$ In reality, however, in all but leases of very short duration, it may be a right that is more illusory than real. If one assumes that $B$ and others similarly situated will sever and lease rather than defer to the will of a cotenant when the choice is presented, the empirical impact of the Tenhet rule on the institution of joint tenancy may well be similar to that of a rule that completely severs the estate when one joint tenant executes a lease.

\section{Quiet Enjoyment}

Under Civil Code section 1927, a covenant for quiet enjoyment is implied in every lease. ${ }^{66}$ The Tenhet opinion thus raises the question whether the lessee of one joint tenant has an action for breach of the covenant of quiet enjoyment against the lessor's estate, should the survivor eject the lessee. This question is important because most marital property is held in joint tenancy form. If the cotenants are spouses, the survivor may eject the lessee only to find that the lessee has a claim diminishing the value of the deceased spouse's estate to which the survivor qua spouse is entitled. 67

The primary argument against giving the lessee a cause of action is that the lessee has record notice of the joint estate. Having such notice, the lessee may be said to have accepted the risk that the term may be cut short by the death of the lessor. That is, the lease is to be construed as a variety of life estate pur autre vie. Thus ejectment by the survivor creates no cause of action in favor of the lessee. ${ }^{68}$

65. 18 Cal. 3d at 160, 554 P.2d at 337, 133 Cal. Rptr. at 17.

66. CAL. CIV. CODE $§ 1927$ (West 1954).

67. That is to say, it is likely that the surviving spouse will be entitled to a significant portion, if not all, of the decedent's estate. A recent empirical study shows that a large majority of spouses bequeath all of their estates to the surviving spouse. M. SUSSMAN, J. CATES \& D. SMITH, THE FAMILY AND INHERITANCE 86-90 (1970). In the absence of a will a surviving spouse is entitled to all community property, CAL. PROB. CODE $\S 201$ (West 1956), and to between onethird and all of the decedent's separate property, id. \$\$220-224. Although community property that devolves to the surviving spouse is not administered with the estate in all cases, $i d . \$ 202$ (West Supp. 1977), in those cases where it is not the survivor is personally liable for post-nuptial contracts made by the deceased spouse to the extent of the community property she receives. Id. $\$ 205$ (West Supp. 1977), CAL. Crv. CoDE $\$ 5116$ (West Supp 1977).

Of course, the joint tenancy that is the subject of the dispute is the survivors's separate property and, as such, not subject to the decendent's debts. Thus, in cases where the decedent had no other assets, the surviving spouse is protected from liability. However, since the form of a deed to a married couple is not always determinative of the property's character and property held in joint tenancy form may actually be community property, see note 68 infra, it might be wondered whether the lessee can assert the leased property was in fact community property and hence subject to liability. Since the fact that the property is recorded as a joint tenancy protects the lessee during the lessor's lifetime against any assertion that the property belongs to the community, see note 68 infra, it would be inequitable to permit the lessee to attack the joint tenancy form after the lessor's death.

68. Similarly, in the case of marital property, the survivor may attempt to avoid liability on the ground that the property was community rather than separate property held as joint 
Several arguments support giving the lessee a right of action, however. Despite record notice of the joint tenancy, when the parties enter into a lease for a specific term, the lessee may reasonably expect the lessor to sever the joint estate to guarantee the lessee the right to possession for the full extent of the term. ${ }^{69}$ Thus when the lessee is dispossessed because of the lessor's failure to sever, a cause of action should accrue. This construction can be buttressed by considerations of fairness. Because the lessor who survives the full extent of the term can enforce the contract against the lessee, it is only equitable that the lessee should be able to enforce the same terms of the contract against the lessor.

An analogy can also be made to the mortgage situation. Although a mortgagee has notice of the joint tenancy and the mortgage is unenforceable

tenants. She might argue that because CAL. Ċrv. CoDE $\$ 5127$ (West Supp. 1977) requires both spouses to join in executing any instrument conveying a leasehold interest for greater than one year, she has a right to void the lease transaction, and hence the lessee has no cause of action. In support of this theory, the cases hold that spouses can present evidence to rebut a joint tenancy deed and show that the property was in fact community property (a joint tenancy deed overcomes the presumption of CAL. CIV. CoDE $\$ 5110$ (West Supp. 1977) that real property acquired by husband and wife is community property, and creates a contrary presumption). E.g., Gudelj v. Gudelj, 41 Cal. 2d 202, 259 P.2d 656 (1953); Tomair v. Tomair, 23 Cal. 2d 754, 146 P.2d 905 (1944); Hansford v. Lassar, 53 Cal. App. 3d 364, 125 Cal. Rptr. 804 (2d Dist. 1975). This rule has, however, never been applied against a bona fide purchaser who has relied on the record title. Griffith, supra note 30 , at $93-95$. The policies underlying the recording acts require that since the spouses have held out the property as a joint tenancy they be estopped from asserting otherwise.

Conversely, the lessee might wish to assert that the property is actually community after the death of the lessor to avoid the rule of Tenhet. Were the property deemed to belong to the community the rights of the parties would be controlled by the management provisions of the community property law. The cases construing these provisions hold that after the dissolution of the community by death or divorce a spouse may avoid a conveyance made without her consent only to the extent of her one-half interest in the property (before dissolution she may avoid such a transaction in its entirety). See Heuer v. Heuer, 33 Cal. 2d 268, 201 P.2d 385 (1949); Britton v. Hammell, 4 Cal. 2d 690, 52 P.2d 221 (1935); Trimble v. Trimble, 219 Cal. 340, 26 P.2d 447 (1933); Bruch, The Legal Import of Informal Marital Separations: A Survey of California Law and a Call for Change, 65 CALIF. L. REv. 1015, 1056 n.149 (1977). Thus, the lease would be valid to the extent of the deceased spouse's interest in the community property. Although third parties such as creditors, heirs, and devisees have been permitted to assert the community character of joint tenancy property (Socol v. King, 36 Cal. 2d 342, 223 P.2d 627 (1950) (executrix); Solomon v. Phillips, 92 Cal. App. 2d 1, 206 P.2d 50 (4th Dist. 1949) (judgment lien creditor)) this rule should not be extended to apply to the lessee. Since the policies of the recording acts dictate that the surviving spouse should not be permitted to assert the property's community character to defeat the lessee's interest during the lifetime of the lessor, see Griffith, supra note 30 , at 94 , it would be unfair to allow the lessee to repudiate the form of the title on which he was permitted to rely. The presumption of Civil Code $\$ 5110$ that a single family dwelling of a husband and wife acquired during marriage by a joint tenancy deed is community property, applies only for the purpose of division of the property upon divorce or separation, and does not indicate a different result in respect to the rights of third parties such as the lessee. Cf. In re Marriage of Bjornestad, 38 Cal. App. 3d 801, 113 Cal. Rtpr. 576 (2d Dist. 1974) (legislative history).

Since, however, a spouse cannot void a lease for one year or less made without her consent, perhaps a person holding under such a lease should be permitted to attack the apparent joint tenancy form to avoid the rule of Tenhet. This is largely an academic question, however, since Tenhet in any event should not be applied to leases of one year or less. See note 16 supra.

69. It could be argued in parity with the rule concerning encumbrances on title under 
against the survivor upon the death of the mortgagor, the underlying contract with the mortgagor creating the obligation which supports the mortgage is not extinguished and may be enforced against the mortgagor's estate. By analogy, a lease is both a contract and an estate in land. ${ }^{70}$ Thus, although the lessee's term cannot be recovered, because the survivor takes by paramount title, an action for damages against the lessor may still be available.

In addition, the general rule is that if the lessee is dispossessed by the holder of a paramount title there exists a cause of action against the lessor for damages. ${ }^{71}$ Giving the lessee of one jomt tenant a cause of action seems consistent with this rule. This conclusion is supported by the fact that a lease with a covenant for quiet enjoyment implies that the lessor had the power and right to demise. ${ }^{72}$

Finally, in support of the lessee, the American cases hold that a lease made by a tenant for life terminates upon the lessor's death, but if the lease contains a covenant for quiet enjoyment, express or implied, the estate of the lessor is liable for a breach thereof. ${ }^{73}$

Since the measure of damages for breach of the covenant of quiet enjoyment is the market value of the term minus the rent reserved ${ }^{74}$ the Tenhet court's "horrible hypothetical" of the ninety-nine year lease for one dollar per year may still remain.

\section{III}

\section{ALTERNATIVE SOLUTIONS}

The Tenhet court changed established law by analogizing the problem presented when one joint tenant leases for a term to the California decisions involving mortgages and other liens on joint tenancy property. Questions of technical adequacy aside, the approach taken by the court diverted its attention from an explicit analysis of the balance between the policies favoring each of the three competing interests involved. Implicitly, however, the court has made a value choice favoring the interests of the survivor over those of the lessor and lessee. This section reexamines this choice by comparing it to other rules of law available to the court in terms of the relative priority each assigns to the various interests involved.

CAL. CIv. CODE $\S 1113$ (West 1954) (implied covenant against encumbrances is contained in every grant deed) that since in this context it is presumed that the grantee can expect the grantor to remove any encumbrances on title unless the deed explicitly excepts them from the covenant, Frazer v. Bentel, 161 Cal. 390, 119 P. 509 (1911), likewise the lessee can expect that the lessor will take the necessary steps to ensure the right to possession for the full extent of the term.

70. Parker v. Superior Court, 9 Cal. App. 3d 397, 88 Cal. Rptr. 352 (4th Dist. 1970).

71. Playter v. Cunningham, 21 Cal. 229 (1862); Lost Key Mines, Inc. v. Hamilton, 109 Cal. App. 2d 569, 241 P.2d 273 (3d Dist. 1952).

72. McAlester v. Landers, 70 Cal. 79, 82, 11 P. 505, 506-07 (1886).

73. See Annot., 171 A.L.R. 489, 491 (1947); Annot., 6 A.L.R. 1506, 1507 (1920).

74. Damages for breach of this covenant are governed by CAL. CIV. CODE $\S 3300$ (Wcst 
Tenhet emphasizes the nonleasing cotenant's right of survivorship. Its requirement that to effect a severance an action taken by a joint tenant must "clearly and unambiguously" establish the desire to terminate the joint estate makes clear that any rule of law that does not afford substantial protection to the right of survivorship is unacceptable. This policy is supported by the fact that the joint tenancy form of ownership is often used as a means of passing marital property to a surviving spouse without probate. ${ }^{75}$ Likewise, however, there is a strong state policy favoring the free alienation of land. This is evidenced both by the legislative judgment embodied in Civil Code section $711^{76}$ and in recent decisions holding that restraints on alienation are void unless reasonably necessary to achieve a legitimate purpose. ${ }^{77}$ The third interest at stake is the lessee's right to possession of the land for the term specified by the lease. Although the court determimed that the lessee's rights are sufficiently protected by the recording acts, the statutory implied covenant of quiet enjoyment suggests that the lessee's rights can not be ignored.

Four alternatives are considered below. It is concluded that partial severance during the term of the lease, whereby the survivor takes the reversion subject to the lease, does not significantly prejudice the rights of the survivor, and further better protects the right of the lessee and lessor. Moreover, unlike the Tenhet rule, this solution is technically harmonious with common law authority.

\section{A. Actual Intent}

The rule based on actual intent derives from a rather literal reading of the court's language. Basically it would provide that since express intent is necessary to the creation of a joint tenancy, intent is the controlling factor in its destruction. Essentially the rule would require a judgment under the particular circumstances of each case whether the action taken by a joint tenant actually expresses a desire to terminate the joint tenancy. Under such a rule the courts could give differing treatment, for example, to a one year lease and a ninety-nine year lease.

Such a rule would be highly unsatisfactory. Actual intent does not appear on tract indexes or abstracts of title. The amount of information extrinsic to the record needed to determine intent would be so substantial as to seriously undermine the marketability of jomt tenancy titles, an element

1970), not Cal. Civ. Code $\$ 3304$ (West 1970). Standard Livestock Co. v. Pentz, 204 Cal. 618, 642, 269 P. 645, 655 (1928); Guntert v. City of Stockton, 55 Cal. App. 3d 131, 142, 126 Cal. Rptr. 690, 696 (3d Dist. 1976).

75. See Griffith, supra note 30 , at 88 . See text accompanying notes $30-31$ supra.

76. "Conditions restraining alienation, when repugnant to the interest created, are void." Cal. Civ. Code $\S 711$ (West 1954). See also CaL. Civ. Code $\S 718$ (West Supp. 1977), limiting the term of leases.

77. See, e.g. , Tucker v. Lassen Savings, 12 Cal. 3d 629, 526 P.2d 1169, 116 Cal. Rptr. 633 (1974); Coast Bank v. Minderhout, 61 Cal. 2d 311, 392 P.2d 265, 38 Cal. Rptr. 505 (1964). 
of ownership that should be promoted whenever possible. ${ }^{78}$ If the joint tenancy form of ownership is chosen to avoid the expense and delay of probate, this advantage would be rendered nugatory if quiet title actions were necessary to insure marketability. ${ }^{79}$

\section{B. Total Severance}

The Maryland rule is that the making of a lease by one joint tenant to a third party effects a complete and final severance of the joint tenancy.$^{80}$ This is also sometimes stated to be the English common law rule, but a close examination of the cases does not support this assertion. ${ }^{81}$ It has been preferred by some commentators over temporary severance or no severance, on the theory that the joint tenancy form should be destroyed whenever sufficient technical ground exists, since under modern law there is a presumption favoring tenancy in common, and joint tenancy is disfavored both by statute and judicial decision. ${ }^{82}$

This rule is directly contrary to the rationale of Tenhet, which requires an unequivocal expression of intent to destroy the right of survivorship. It works a severance in excess of that necessary to protect the rights of the lessee or lessor. It should therefore be rejected.

\section{Temporary Severance-Conditional Type}

Under the doctrine of conditional severance, the joint tenancy is severed during the term of the lease with a possibility of revival ${ }^{83}$ If either joint tenant dies during the term of the lease the severance becomes final, but if the term expires while both are still living, the joint tenancy revives. This rule perhaps represents the inost technical application of the four unities concept, and there is substantial authority to support the conclusion that it is the English common law rule. ${ }^{84}$

This approach solves the problem of mutuality. Either the survivor takes an unencumbered fee or a severance is created. It provides some

78. See Comment, The Use of Extrinsic Evidence to Interpret Real Property Conveyances: A Suggested Limitation, 65 CALIF. L. REv. 897 (1977).

79. Swenson \& Degnan, supra note 10, at 501 .

80. Alexander v. Boyer, 253 Md. 511, 253 A.2d 359 (1969).

81. See the cases cited at note 18 supra. In all of the cases where the issue was actually before the court the holding is consistent with a rule of conditional severance during the term of the lease. Given that the English rule concerning the effect of a life estate conveyed by one joint tenant to a third party is that the joint tenancy is severed during the freeholder's life with the possibility of a revival if both joint tenants survive him, see, e.g. Co. LiTT. ${ }^{*} 191$, b; 24 HALSBURY's LAWS, supra note $10, \S 389$; LITTLETON's TENURES $\S 302$ (1903), it is difficult to justify resolving any ambiguity in the cases in favor of complete severance.

82. See, e.g., 2 ALP, supra note $1, \S 6.2 ; 1937$ Comment, supra note 10, at 208. See also Alexander v. Boyer, 253 Md. 511, 253 A.2d 359 (1969) (following the reasoning of these authorities).

83. See Comment, Joint Tenancy in California Revisited: A Doctrine of Partial Severance, 61 CALIF. L. REv. 231 (1973); 1937 Comment, supra note 10.

84. See 1937 Comment, supra note 10, at 208. 
measure of protection to the right of survivorship, because no severance results unless the action taken by a joint tenant is actually inconsistent with survivorship. It is, however, subject to the criticism that an "unintended" severance may result upon the totally unexpected and untimely death of either joint tenant during the term of even a very short lease. It therefore gives an inconstant effect to the policy of protecting the right of survivorship from such harsh and unpredictable consequences. Moreover, a total severance upon the death of either joint tenant is hardly necessary to protect the rights of the lessor and lessee. For example, if the term has only a matter of months to run under the lease at the time of the death of one of the joint tenants, it is an extreme measure to create a final severance. If it is the lessor who has died, it would be preferable to give the survivor the reversion subject to the lease for a few months, rather than to deprive her of her cotenant's moiety altogether. This approach does not seem preferable to that taken by the court.

\section{Temporary Severance-Partial Type}

The doctrime of partial or pro tanto severance is similar to the "no severance" doctrine employed in Tenhet in that in all cases the right of survivorship subsists. ${ }^{85}$ Under partial severance, however, the joint estate continues only in the reversion for the term of the lease. Upon the death of the lessor before the expiration of the term, only the reversion accrues to the survivor. ${ }^{86}$ In the court's parlance this would be equivalent to stating that the joint tenancy is not severed, but the survivor takes the property encumbered by the lease. Technically, however, since the estate has been "split" and the term separated from the freehold for the duration of the lease, the lease is not extinguished upon the death of the lessor. There exists respectable authority stating this to be the English common law rule. ${ }^{87}$

The Tenhet court did not give sufficient consideration to this alternative. It has been argued above that the court's primary rationale for the conclusion that the lease expires upon the lessor's death is technically inadequate in terms of the traditional conceptions of the term for years and the four unities. Apparently as an alternative rationale, the court proffered the statement that the "very purposes" of joint tenancy would be defeated if the erstwhile joint tenant was bound by the lease after the death of the lessor. The "horrible hypothetical" of the minety-nine year lease for one dollar per year is the only analysis offered to support this conclusion. This hypothetical was used by the court to demonstrate that it is mamifestly unfair to allow

85. See authorities cited in note 83 supra.

86. For example, if $A$ and $B$ are joint tenants, and $B$ leases for a term of years to $C$, then $A$ and $C$ are tenants-in-common for the duration of the term, and $A$ and $B$ remain joint tenants in the reversion. If $B$ predeceases $A$ before the term expires, $A$ takes $B$ 's moiety in the reversion by survivorship.

87. See the third group of authorities cited in note 18 supra. 
one joint tenant both to lease beyond his death and to have the chance of taking the cotenant's interest by survivorship. This argument, however, assumes that the leasing joint tenant impairs the value of his moiety. But in the vast majority of cases, it is likely that incident to the reversion will be a rent equal in value to the possessory rights to the lessor's moiety. Since attornment of the tenant is no longer necessary to make a valid and effectual grant of rents or of the reversion, ${ }^{88}$ the right to the rents accruing after the death of the lessor would pass by the right of survivorship to the survivor ${ }^{89}$ Thus, the court's conclusion that the market value of the property taken by the survivor is impaired may apply only in extremely rare instances. Moreover, the survivor has the right to be let into or remain in possession of the entire premises with the lessee. ${ }^{90}$

The court's concern that the value of the lessor's moiety will be impaired at the time the right of survivorship accrues does not accord with common sense notions about rational economic choice. If $A$ and $B$ are joint tenants it is of course possible that $B$ could grant to $C$ a term for ninety-nine years at one dollar for "personal reasons." Such transactions are likely to be extremely rare. For example, $B$ is unlikely to make such a lease to spite $A$, since the value of his property will have been denigrated should $B$ ultimately be the survivor.

Perhaps a greater danger is presented by the possibility that $B$ may attempt to extract the rent for the entire term in advance. For a lease of any duration, however, this would be unlikely. From $B$ 's point of view, a long term lease may be preferable to a conveyance in fee due to a desire eventually to realize the appreciation on the underlying fee, or a wish to avoid the tax consequences of a lump sum payment. Since $B$ cannot be certain of surviving $A$, however, the immediate adverse consequences stemming from a graduated tax system are likely to militate in favor of a yearly rent. From the lessee's poimt of view the primary economic advantage of a lease is the acquisition of a long term possessory right to the property for substantially less capital than it would take to purchase the fee. This factor will militate against a lump sum payment of the rent for the term. Thus, unlike a mortgage, a lease transaction is not likely to impair the value of the property because a periodic rent will in most cases be incidental to the reversion. Indeed, if the rule of partial severance had been applied in

88. CAL. Crv. CODE $\S 1111$ (West 1954). Attornment was abolished by the Statute of Anne, 4 \& 5 Anne, c. 3 \& 9 (1705). See Cal. Civ. Code $\$ 821$ (West 1954).

89. See Comment, Joint Tenancy in California Revisited: A Doctrine of Partial Severance, 61 CALIF. L. REv. 231, 244-47 (1973). Before the abolishment of attornment the term would continue discharged of the rent. Anonymous (1590), DYER *187, a; 1 T. PLATT, supra note 17 , at $129-30$.

90. See Swartzbaugh v. Sampson, 11 Cal. App. 2d 451, 54 P.2d 73 (4th Dist. 1936). 
Tenhet, Hazel would have received total rents of $\$ 1500$ during the ten year term of the lease, nearly half the value of the property at the time the lease was executed. A holding that Hazel takes the reversion by survivorship subject to the lease would certainly have been an equitable result on the facts of the case.

Because a rent reflecting the value of the possessory rights conveyed under the lease is likely to be incident to the reversion in a vast majority of cases, partial severance adequately protects the expectations of the survivor. It therefore seems unjustified substantially to impair a joint tenant's ability to alienate by lease, even during her own lifetime, simply because it is possible to conceive of circumstances where inequity will result. As a practical matter the lessor, upon predeceasing the erstwhile joint tenant, will in most cases have received precisely that to which the court states he is entitled-the rents accruing during his lifetime. The rule comports well with the function of joint tenancy as a testamentary device; the result under partial severance will be similar to the result had the parties held the property as tenants in common and executed mutual wills. Moreover, under partial severance the rights of the lessee are fully protected. This may be more important than the court recognizes if the lessee has an action for breach of the covenant of quiet enjoyment against the lessor's estate. ${ }^{91}$ If the lessee has such an action, the protection afforded the survivor by Tenhet may be illusory.

Partial severance thus seems better to accomodate the competing interests of the survivor, the lessor and the lessee than the rule of Tenhet. At the same time, partial severance is more consistent with established precedent. Under partial severance it is not necessary to reject a uniform line of authority ${ }^{22}$ holding that one joint tenant may make a lease that is valid beyond her death. Further, whether the continuation of the four unities or the consistency of the action taken with respect to survivorship be the test of severance, the doctrine of partial severance is preferable. To illustrate, if $A$ and $B$ are joint tenants, and $B$ leases to $C$, upon the making of the lease a "split estate" is created whereby $A$ and $C$ are tenants in common in possession during the lease, and $A$ and $B$ remain joint tenants in the reversion. Because the reversionary interest of each is created by the same title, at the same time, is of the same quality and quantity, and gives each the same rights of possession (that is, to enter upon expiration of the lease) the four unities are preserved in the reversion. A partial severance is created in the term, precisely to the extent the lease is inconsistent with the four

91. See text accompanying notes 66-74 supra.

92. See notes 17 and 18 supra. 
unities. Likewise, if consistency with survivorship be the test, pro tanto severance is created exactly to the extent the action of the lessor is inconsistent with survivorship.

Finally, partial severance is not contrary to the Tenhet rationale that since express intent is needed to create a joint tenancy, similarly a clear expression of intent is necessary to terminate the joint tenancy relationship. By making a lease for ten years it certainly cannot be gainsaid that the lessor expressed a clear and unambiguous intent to give the lessee the right to possession for ten years. The doctrine of partial severance creates a pro tanto severance only to the extent necessary to give effect to this express intent.

\section{CONCLUSION}

The decision in Tenhet, although it purports to build on established authority, actually repudiates a uniform body of precedent holding that a joint tenant may unake a lease that is valid beyond his death and binding on the survivor. It thus inakes new law. The structure of the opinion is nodeled on the California decisions involving mortgages and other liens on joint tenancy property. Because the rationale of these decisions rests on the common law rule that survivorship is preferred to inere charges or encumbrances on the land, and because a lease for a term of years was heretofore never thought to be within the ambit of this rule, the logic of the opinion undermines the traditional four unities test of severance. Although the court perceived severance to be the central issue of the case, because it involved a contest between the survivor and the lessee, under prior precedent the court should have disposed of the case on other grounds, before turning to the question of severance. Thus, the rationale of the case should not serve as a doctrinal basis for future decisions.

At a deeper level the central holding of the case is that a joint tenant may not lease for a term continuing beyond his death. This result represents a legitimate attempt by the court to make the institution of joint tenancy conform to its modern function. Unfortunately the court, relying on the aforementioned technical ground, did not focus sufficiently on providing an explicit analysis of the coinpeting policies and interests involved. Although the result apparently affords a high level of protection to the right of survivorship, which is justified since joint tenancy functions largely as a testamentary device for marital property, the court did not fully consider the impact of the decision on the right of a joint tenant to alienate by lease even during his own lifetmie. Moreover, the court does not appear to have considered that the lessee may have a right of action against the lessor's estate for breach of the covenant of quiet enjoyment, and hence the devil 
may be admitted through the back door who was just expelled through the front, and the rule of Tenhet undermined. A reconsideration of the alternative rules rejected by the court leads to the conclusion that the doctrine of partial severance would have provided a better rule of law.

John A. Sodergren*

* A.B. 1970, University of California, Irvine; A.M. 1973, Harvard University; thirdyear student, Boalt Hall School of Law. 